and B. C. Coull, eds), pp. 219-242. Univ. of South Carolina Press, South Carolina.

Nixon, S. W., Oviatt, C. A., Frithsen, J. \& Sullivan, B. (1986). Nutrients and the productivity of estuarine and coastal marine ecosystems. $J$. Limnol. Soc. Sth. Afr. 12, 43-71.

Nixon, S. W., Pilson, M. E. Q., Oviatt, C. A., Donaghay, P., Sullivan, B., Seitzinger, S., Rudnick, D. \& Frithsen, J. (1984). Eutrophication of a coastal marine ecosystem-an experimental study using the MERL microcosms. In Flows of Energy and Materials in Marine Ecosystems (M. J. R. Fasham, ed.), pp. 105-135. Plenum, New York.

Oviatt, C. A., Buckley, B. A. \& Nixon, S. W. (1981). Annual phytoplankton metabolism in Narragansett Bay calculated from survey field measurements and microcosm observations. Estuaries 4, 167175 .

Oviatt, C. A., Frithsen, J., Gearing, J. \& Gearing, P. (1982). Low chronic additions of No. 2 fuel oil: chemical behavior, biological impact and recovery in a simulated estuarine environment. Mar. Ecol. Prog. Ser. 9, 121-136.

Oviatt, C. A., Keller, A., Sampou, P. A. \& Beatty, L. L. (1986a). Patterns of productivity during eutrophication: A mesocosm experiment. Mar. Ecol. Prog. Ser. 28, 69-80.

Oviatt, C. A., Rudnick, D. T., Keller, A. A., Sampou, P. A. \& Almquist, G. T. (1986b). A comparison of system $\left(\mathrm{O}_{2}\right.$ and $\left.\mathrm{CO}_{2}\right)$ and ${ }^{14} \mathrm{C}$ measurements of metabolism in estuarine mesocosms. Mar. Ecol.Prog. Ser. 28, 57-67.

Oviatt, C. A., Walker, H. \& Pilson, M. E. Q. (1980). An exploratory analysis of microcosm and ecosystem behavior using multivariate techniques. Mar. Ecol. Prog. Ser. 2, 179-191.

Pilson, M. E. Q. (1985a). On the residence time of water in Narragansett Bay, Estuaries 8, 2-14.

Pilson, M. E. Q. (1985b). Annual cycles of nutrients and chlorophyll in Narragansett Bay, Rhode Island. J. Mar. Res. 43, 849-873.

Pilson, M. E. Q., Oviatt, C. A. \& Nixon, S. W. (1980). Annual nutrient cycles in a marine ecosystem. In Microcosms in Ecological Research (J. P. Giesy, ed.), pp. 753-778. DOE Symposium Series, Augusta, Georgia.
Pomeroy, L. R., Smith, E. E. \& Grant, C. M. (1965). The exchange of phosphate between estuarine water and sediments. Limnol. Oceanogr. 10,167-172.

Pratt. D. M. (1949). Experiments in the fertilization of a salt water pond. J. Mar. Res. 8, 36-59.

Rigler, F. H., (1956). A tracer study of the phosphorus cycle in lake water. Ecology 37, 550

Rowe, G. T., Clifford, C. H. \& Smith, K. L.. Jr. (1977). Nutrient regeneration in sediments off Cap Blanc, Spanish Sahara. Deep-Sea Res. $24,57-63$

Rowe, G. T., Clifford, C. H., Smith, K. L. \& Hamilton, R. C. (1975) Benthic nutrient regeneration and its coupling to primary productivity in coastal waters. Nature 255, 215-217.

Rowe, G. T. \& Howarth, R. (1985). Early diagenesis of organic matter in sediments off the coast of Peru. Deep-Sea Res. 32, 43-45.

Ryther, J. H., Yentsch, C. S., Holburt, E. M. \& Vaccaro, R. F. (1958) The dynamics of a diatom bloom. Biol. Bull. 115, 257-268.

Santschi, P. H., Adler, D., Amdurer, M., Li, Y.-H. \& Bell, J. J. (1980) Thorium isotopes as analogues for particle-reactive pollutants in coastal marine environments. Earth Planet. Sci. Lett. 47, 327-335.

Santschi, P. H., Carson, S. \& Li. Y.-H. (1982). Natural radionuclides as tracers for geochemical processs in MERL mesocosms and Narragansett Bay. In Marine Mesocosms (G. D. Grice and M. R. Reeve, eds), pp. 97-109. Springer Verlag, New York.

Schindler, D. W., Armstrong, F. A. J., Holmgren, S. K. \& Brunskill, G. J (1971). Eutrophication of Lake 227, experimental lakes area, Northwestern Ontario, by addition of phosphate and nitrate. J. Fish Res. Bd. Canada 28, 1763-1782.

Sullivan, B. K. \& McManus, L. T. (1986). Factors controlling seasonal succession of the copepods Acartia hudsonica and A. tonsa in Narragansett Bay, Rhode Island: temperature and resting egg production. Mar. Ecol. Prog. Ser. 28, 121-128.

Vargo, G. A., Hutchins, M. \& Almquist, G. (1982). The effect of low, chronic levels of No. 2 fuel oil on natural phytoplankton assembiages in microcosms: A species composition and seasonal succession. Mar. Environ. Res. 6, 245-264.

\title{
Global Warming and Increasing Population Densities: a Prescription for Seal Plagues
}

\author{
D. M. LAVIGNE* and O. J. SCHMITZ ${ }^{\ddagger}$ \\ * Department of Zoology, University of Guelph, Guelph, Ontario, Canada N1G 2WI \\ ${ }^{\dagger}$ School of Natural Resources, University of Michigan, Ann Arbor, MI 48109-1115, USA \\ ₹Present address: Department of Zoology, University of British Columbia, Vancouver, British Columbia, Canada V6T 1W5
}

\begin{abstract}
Application of Ockham's Razor to data from documented mass mortalities in pinniped populations suggests that unseasonably warm temperatures and high densities of seals, and not 'invading harp seals', marine pollution and suppressed immune systems, triggered the 1988 seal plague in the North Sea.
\end{abstract}

During the summer of 1988 , more than 17000 harbour seals died along the coasts of Scandinavia and Europe (Dietz et al., 1989) in the most recent mass mortality to strike a pinniped (seals, sea lions, fur seals and walrus) population (Geraci et al., 1982). The ultimate cause of this 'seal plague' has been identified as a previously unknown morbillivirus (Family Paramyxoviridae), now called phocine distemper virus (PDV) (Mahy et al., 1988; Cosby et al., 1988). Other morbilliviruses cause distemper in dogs, measles in humans, and rinderpest in ungulates (Mahy et al., 1988; Miller, 1989). Where PDV originated and why it was so virulent in harbour seals remains the subject of much speculation and controversy (Anon., 1988a; Dickson, 1988; Goodhart, 1988; Harwood \& Reijnders, 1988; Holdgate, 1988; McGourty, 1988a,b; Eis, 1989; Harwood, 1989; Holt, 1989; Law et al., 1989; Osterhaus \& Vetter, 1989; Simons \& Johnson, 1989a,b). 
It has been suggested that the 1988 epizootic began with an 'invasion' of non-endemic harp seals, Phoca groenlandica, which transmitted PDV to previously uninfected harbour seals (Goodhart, 1988; Harwood, 1989; Miller, 1989). It has also been argued that these harbour seals may have been particularly susceptible to infection because their immune systems were suppressed by the action of environmental contaminants, particularly, polychlorinated biphenyls (PCBs) (Anon., 1988a; Dickson, 1988; Harwood \& Reijnders, 1988; Holdgate, 1988; McCourty, 1988a,b; Eis, 1989; Harwood, 1989; Holt, 1989; Law et al., 1989; Osterhaus \& Vetter, 1989; Simons \& Johnson, 1989a,b). Yet, consideration of previous mass mortalities of pinnipeds suggests that, once again (see Geraci et al., 1982), other factors may have been more important, especially during the initial stages of the outbreak.

We have re-examined the major mass mortalities that have been documented in pinniped populations (Table 1 ). In those cases where the relevant observations were recorded, population sizes were said to be increasing or seal densities on shore were described as being unusually high. In the majority of cases, ambient temperatures were reported to be unseasonably warm.

To investigate the possible relationship between environmental temperatures, seal densities and the outbreak of epizootics, we compiled data on local mean monthly air temperatures during the years of the mass mortalities and compared these with the mean monthly air temperatures for the preceding ten years. In the five instances with available data, mean monthly temperatures preceding the mass mortalities were higher than the ten-year averages (Fig. 1). In each case, the mass mortalities began following three months when mean air temperatures were $1.0-3.0^{\circ} \mathrm{C}$ higher than the preceding ten-year average. Even in Iceland, where 1918, the year of their seal plague, is reported to have had the coldest winter on record (Dietz et al., 1989), two of the three months immediately preceding the detection of the outbreak in June were warmer than the ten-year monthly averages (Fig. 1A).

There are no quantitative data to link environmental

TABLE 1

Population densities and environmental temperatures preceding major mass mortalities in pinniped populations, as they were originally described.

\begin{tabular}{|c|c|c|c|c|c|}
\hline $\begin{array}{l}\text { Location } \\
\text { of outbreak }\end{array}$ & Date & Species & $\begin{array}{c}\text { Population } \\
\text { density }\end{array}$ & $\begin{array}{c}\text { Environmental } \\
\text { temperature }\end{array}$ & $\begin{array}{r}\text { Pathogen } \\
\text { Disease }\end{array}$ \\
\hline Iceland $d^{a, b}$ & 1918 & harbour seal, Phoca vitulina & $\mathrm{nd}^{*}$ & extremely cold & pneumonia \\
\hline Antarctica & 1955 & crabeater seal, Lobodon carcinophagus & $10 \times$ normal & mild & virus" \\
\hline Alaska $^{d}$ & 1978 & walrus, Odobenus rosmarus & high & nd & none \\
\hline New England & $1979 / 80$ & harbour seal, Phoca vitulina & unusually large & unseasonably warm & virus \\
\hline Lake Baikal & $1987 / 88$ & Baikal seal, Phoca sibirica & nd & nd & virus. th. h. i \\
\hline Kattegat-Skagerrak ${ }^{a}$ & 1988 & harbour seal, Phoca vitulina & growing population $^{j}$ & unusually mild & virus ${ }^{k .1}$ \\
\hline
\end{tabular}

Sources: ${ }^{\mathrm{a} D i e t z}$ et al. (1989), ${ }^{\mathrm{b}}$ Bárdarson (1931), ' Laws \& Taylor (1957), ${ }^{\mathrm{d}}$ Fay \& Kelly (1980), ${ }^{\mathrm{C}}$ Geraci et al. (1982), ${ }^{\mathrm{A}}$ Anon. (1988c), ${ }^{\mathrm{B}} \mathrm{Gracher}$

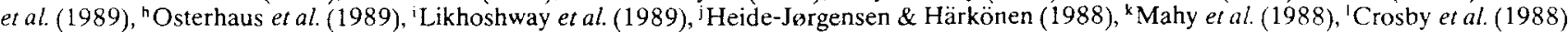

*nd-no data provided.

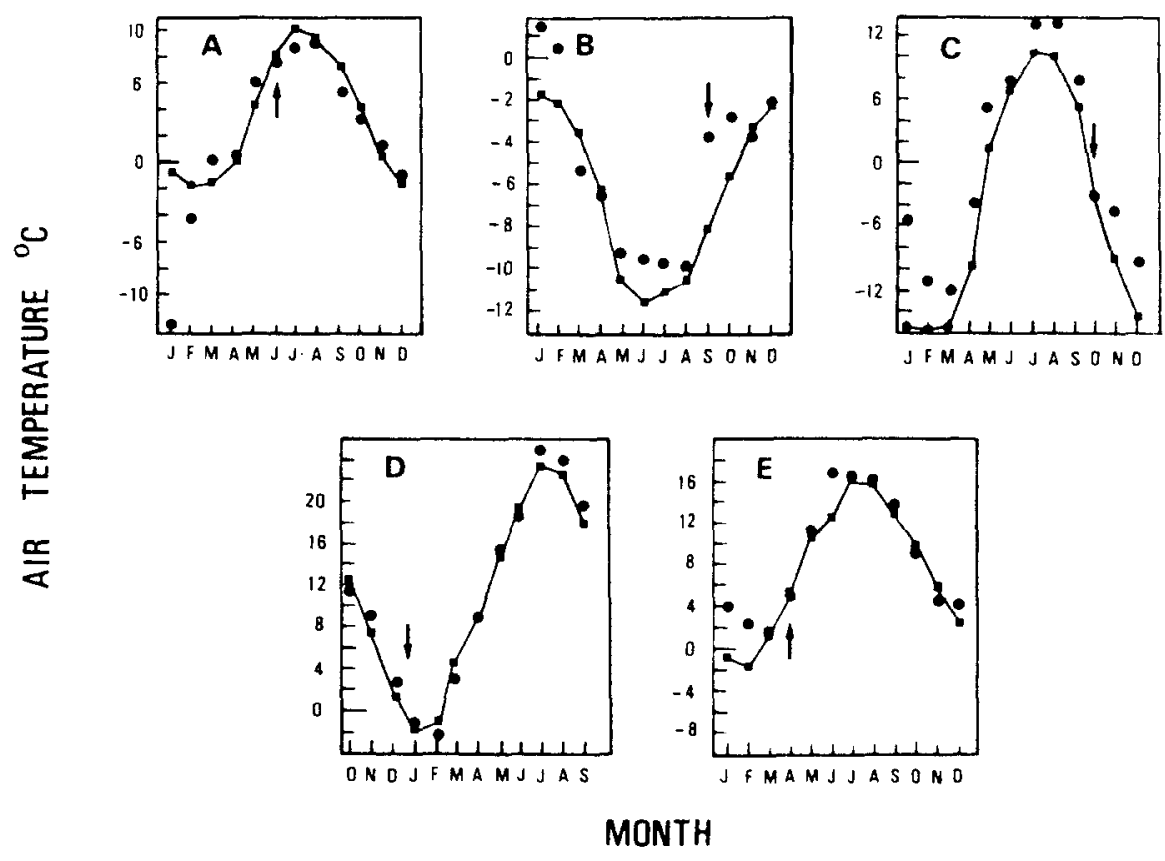

Fig. 1 Comparison of local mean monthly air temperatures during mass mortalities in the seal populations listed in Table $!$ (circles), with mean monthly air temperatures for ten years preceding the outbreaks (squares). Temperature data were obtained from Ruffner \& Bair (1987) (for New England and Alaska) and from the Meteorological Institute of Iceland (Iceland). the National Meteorological Archive, UK (Hope Bay, Antarctica), and the Danish Meteorological Institute (Kattegat-Skagerrak). We have been unable to obtain temperature data for Lake Baikal. A. harbour seals, Iceland, 1918; B. crabeater seals, Hope Bay, Antarctica, 1955; C. walruses, Alaska, 1978; D. harbour seals, New England. 1979; E. Kattegat-Skagerrak. 1988. Arrows indicate month in which each mass mortality began. 
temperatures and densities of seals on shore prior to a mass mortality. Relevant data are, nonetheless, available for harbour seals at Sable Island, Canada (Boulva, 1973). In this population, animals usually remain in the water until air temperatures rise to about $-1^{\circ} \mathrm{C}$. As temperatures continue to increase, the seals begin to 'haul out' on the beaches to bask and, between -1 and $1^{\circ} \mathrm{C}$, densities of animals on shore increase by orders of magnitude. They remain at high levels to at least $5.6^{\circ} \mathrm{C}$ (Fig. 2). Thus, if temperatures are unseasonably warm, harbour seals may haul out when they would otherwise be in the water. During times when they are normally on shore, higher temperatures may also cause them to congregate at greater densities and for longer durations than usual.

Consistently, the proportion of walruses, Odobenus rosmarus, on shore has been observed to increase from zero to about $100 \%$ as air temperatures increase from -25 to $-20^{\circ} \mathrm{C}$ and densities remain high at temperatures up to about $5^{\circ} \mathrm{C}$ (Ray \& Fay, 1968).

Contrary to recent claims (Dietz et al., 1989), our assessment suggests that there is a common mechanism triggering mass mortalities in pinnipeds. We propose that high densities of pinnipeds on land, frequently mediated by unseasonably warm temperatures, set the stage for the rapid invasion of an opportunistic pathogen by increasing the availability of potential hosts. This is the most parsimonious explanation for mass mortalities in pinnipeds, including the recent seal plague that devastated European harbour seals, Phoca vitulina, in 1988. Such a scenario is entirely consistent with documented epizootics in other animals, including epidemics in humans (Cooper \& MacCallum, 1984).

Of course, high densities alone will not necessarily result in an epizootic. This will only occur if a pathogen is present and becomes established in the population. Indeed, the walrus mortalities in Alaska were largely the result of pregnant females and pups being crushed because animals were overcrowded. No disease agent was identified (Fay \& Kelly, 1980). Nonetheless, if a highly contagious disease, like phocine distemper, does become established in a population, it can easily spread to susceptible animals, either by direct contact between individuals or by airborne transmission (Andrewes et al., 1978; Cooper \& MacCallum, 1984). This may account for the widespread dispersal of phocine distemper during the seal plague of 1988.

The suggestion that marine pollution played a significant role in the 1988 seal plague cannot be ruled out entirely. Nonetheless, this particular epizootic began in a population that had been growing at an annual rate of about $12 \%$, in spite of whatever contaminants might have been present (Heide-Jørgensen \& Härkönen, 1988). Moreover, contaminant levels in the affected seals appeared to be lower than in the previous decade (Anon., 1988b) and the plague failed to penetrate far into the Baltic Sea where contaminant levels are high (Helle et al., 1976) but seal densities are relatively low (Almkvist, 1982). Furthermore, pollution is not a common factor in mass mortalities of pinnipeds; it is unlikely, for example, to have been involved in those in Iceland in 1918 and at Hope Bay, Antarctica in 1955.

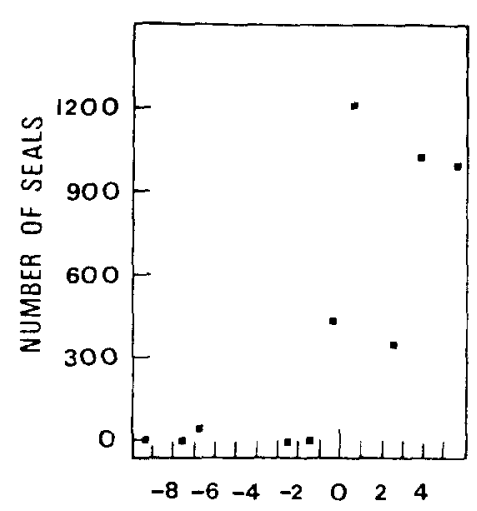

AIR TEMPERATURE ${ }^{\circ} \mathrm{C}$

Fig. 2 Relationship between ambient air temperatures and animal abundance on shore for harbour seals on Sable Island. Plotted from data provided in Boulva (1973). This isolated population of harbour seals numbered 1200-1500 animals at the time of the study (Boulva, 1973).

Of course, if environmental contaminants (Thomas \& Faith, 1985; Vos et al., 1988) or exposure to unusually hot or cold temperatures (Novak et al., 1989) were to induce immunosuppression, something that has yet to be observed in seals prior to an epizootic, the chances of a disease outbreak would certainly be increased.

Similarly, the notion that the seal plague of 1988 was initiated by harp seals, which carried PDV from the Barents Sea to the Kattegat-Skagerrak and infected harbour seals (Goodhart, 1988; Harwood, 1989; Miller, 1989), is not consistent with the available data. The most recent major 'invasion' of harp seals occurred in northern Norway in 1987 (T. Oritsland, pers. comm.). If these harp seals had been capable of initiating an epizootic in harbour seals, they should have done so in 1987 , not 1988 , especially since the typical incubation period for a morbillivirus like canine distemper is about ten days (Andrewes et al., 1978). Furthermore, if harp seals were the source of PDV, the initial outbreak should have occurred in harbour seals in northern Norway and subsequently spread south. Instead, the plague began in the south (Kattegat-Skagerrak) and never reached harbour seals in northern Norway (Dietz et al., 1989).

That small changes in ambient temperatures can increase the likelihood of an epizootic in pinniped populations has profound implications for the future. If we are indeed entering a period of global warming, because of natural events or the greenhouse effect, we would predict that the incidence of mass mortalities in pinnipeds will increase, at least in those species that exhibit marked changes in density in response to relatively small changes in environmental temperatures. Consistently, four of the six documented mass mortalities of pinnipeds have occurred since 1978 (Table 1), a period that includes some of the warmest years in the 20th century (Barron, 1989; Revkin, 1989). Moreover, current models of global climatic change predict that the greatest temperature difference will occur in polar and subpolar regions (Revkin, 1989; Barron, 1989), precisely where pinnipeds live (Davies, 1958; Lavigne \& Kovacs, 1988).

Candidates for future epizootics include northern elephant seals, Mirounga angustirostris, and antarctic fur 
seals, Arctocephalus gazella. Their numbers are increasing exponentially (Cooper \& Stewart, 1983; McCann \& Doidge, 1987; Heide-Jørgensen \& Härkönen, 1988) and local densities could be further inflated during an unseasonably warm spell.

In contrast, it is unlikely that endangered Mediterranean monk seals, Monachus monachus, are threatened by PDV from North Sea harbour seals (Harwood, 1989). They are far removed from the infected area and they are currently living at very low densities (Sergeant et al., 1978), being one of the most endangered mammalian species on the planet.

For related reasons, we would not have expected the seal plague of 1988 to have repeated itself during the summer of 1989 (Harwood et al., 1989), even though temperatures were again unseasonably high (air temperature data for 1989 were obtained from the Danish Meteorological Institute, Copenhagen, Denmark and The Meterological Office, Berkshire, UK). Because of the reduction in population size due to the epizootic and because many of the surviving animals had developed immunity to PDV (Harwood et al., 1989), the number of potentially susceptible animals remaining in the population would likely be too small to sustain another epizootic. Consistently, only a few deaths attributed to PDV were reported in 1989.

In recent years, there have also been a number of mass mortalities involving cetaceans (whales, dolphins and porpoises). In two cases-humpback whales, Megaptera novaeangliae, at Cape Cod in 1987, and bottlenosed dolphins, Tursiops truncatus, along the US eastern seaboard in 1987-88-the deaths were attributed to the consumption of toxic algae (Perrin, 1988; Geraci, 1989). Widespread blooms of toxic algae are, however, also associated with abnormally high temperatures (Underdal et al., 1989). As with pinnipeds, changes in environmental temperatures can have marked effects on the distribution and local densities of some whales, e.g. beluga whales, Delphinapteras leucas (Hansen, 1987).

Accordingly, we wonder if the temporal associations of red tides and recent mass mortalities of marine mammals, including both harbour seals (Dietz et al., 1989) and dolphins (Geraci, 1989), are merely coincidental. As in the case of the pinnipeds, the mass mortalities of humpback whales (December 1987) and dolphins (June 1987) along the US east coast began at times when both air temperatures (NOAA National Climatic Data Center, Asheville, NC, pers. comm.) and sea surface temperatures (Strong, 1989) were unseasonably warm. Perhaps our hypothesis that increased environmental temperatures provide requisite conditions for mass mortalities also applies to cetaceans?

Regardless, the identification of a pattern in the mass mortalities of pinnipeds provides a prescription for anticipating such events in the future.

We thank S. Innes, S. Skúlason and S. Hansen for fruitful discussions and comments on the MS. R. C. Anderson, K. M. Kovacs, T. D. Nudds, J. B. Sprague and R. E. A. Stewart also reviewed the MS. This research was funded by an operating grant to DML from the Natural Sciences and Engineering Research Council of Canada.
Andrewes. C., Pereira, H. C. \& Wildy, P. (1978). Viruses of Vertebrates 4 th ed.. Bailliere Tindall, London.

Anon. (1988a). Blinded by pollution. New Scientist 119, 27.

Anon. (1988b). Tentative status on the situation for the harbour seal populations (Phoca vilulina) in Danish waters, June 20th 1988. Report prepared for the international expert meeting on death of seals and growth of algae in the North and Baltic Sea. 23-24 June. 1988 , Bonn.

Anon. (1988c). Distemper found in Soviet seals in April. New Scientist 119.29.

Almkvist, L. (1982). Baltic marine mammals-A status report. International Council for the Exploration of the Sea, C.M. 1982/ N:16.

Bárdarson. G. G. (1931). Selafárid a Húnaflóa 1918. Nátuírufraedingurinn 1, 27-28 (in Icelandic, English translation by S. Skúlason|.

Barron. E. J. (1989). Earth's shrouded future. The Sciences 29(5), 1420.

Boulva. J. (1973). The harbour seal (Phoca vitulina concolor) in eastern Canada. Ph.D. Thesis, Dalhousie University. Halifax, NS, Canada.

Cooper. C. C. \& Stewart, B. S. (1983). Demography of northern elephant seals, 1911-1982. Science 219,969-971.

Cooper, J. I. \& MacCallum, F. O. (1984). Viruses and the Environment Chapman and Hall, New York.

Cosby, S. L., McQuaid, S., Duffy, N., Lyons. C., Rima, B. K., Allan, G. M., McCullough, S. J., Kennedy, S., Smyth, i. A., McNeilly, F. \& Craig, C. (1988). Characterization of a seai $A$ orbillivirus. Nature $336,115-116$.

Davies, J. L. (1958). The Pinnipedia: An essay in zoogeography. The Geographical Review XLVIII, 474-493.

Dietz, R., Heide-Jørgensen, M.-P., \& Härkönen, T. (1989). Mass deaths of harhor seals (Phoca vilulina), in Europe. Ambio 18, 258-264.

Dickson, D. (1988). Mystery disease strikes Europe's seals. Science 241, 893-895.

Eis, D. (1989). Simplification in the etiology of recent seal deaths Ambio 18, 144

Fay, F. H. \& Kelly, B. P. (1980). Mass natural mortality of walruses (Odobentus rosmans) at St. Lawrence Island, Bering Sea, Autumn 1978. Arctic 33, 226-245.

Geraci, J. (1989). Clinical investigation of the 1987/88 mass mortality of bottlenose dolphins along the U.S. central and south Atlantic coast. Final report to National Marine Fisheries Service and U.S. Navy, Office of Naval Research and Marine Mammal Commission, April 1989

Geraci, J., St. Aubin, D. J., Barker, I. K., Webster. R. G., Hinshaw, V. S., Bean, W. J., Ruhnke, H. L., Prescott, J. H., Early, G., Baker, A. S., Madoff, S. \& Schooley, R. T. (1982). Mass mortality of harbor seals: pneumonia associated with influenza A virus. Sctence 215, 11291131 .

Goodhart, C. B. (1988). Did virus transfer from harp seals to common seals? Nature 336, 21.

Grachev, M. A., Kumarev, V. P., Mamaev, L. V., Zorin, V. L., Baranova, L. V., Denikina, N. N., Belikov, S. I., Petrov, E. A.. Kolesnik, V. S.. Kolesnik, R. S., Dorofeev, V. M., Beim, A. M., Kudelin, V. N. Nagieva. F. G. \& Sikdorov, V. N. (1989). Distemper virus in Baikal seals. Nature 338, 209.

Hansen, S. (1987). White whale (Delphinapterus leucas) distribution and abundance in relation to water temperature, salinity, and turbidity in the Churchill River Estuary. M.Sc. Thesis, Laurentian University, Sudbury, ON, Canada.

Harwood. J. (1989). Lessons from the seal epidemic. New Scientist 120, $38-42$

Harwood, J. \& Reijnders, P. (1988). Seals, sense and sensibility. New Scientist 120, 28-29.

Harwood, J., Carter, S. D., Hughes, D. E., Bell, S. C., Baker, J. R. \& Cornwell, H. J. C. (1989). Seal disease predictions. Nature 339, 670).

Heide-Jørgensen, M.-P. \& Härkönen, T. J. (1988). Rebuilding seal stocks in the Kattegat-Skagerrak. Marine Mammal Science 4, 231246.

Helle, E., Olsson, M. \& Jensen, S. (1976). PCB levels correlated with pathological changes in seal uteri. Ambio 5, 261-263.

Holdgate, M. (1988). Pollution: Guilty or not guilty. The Pilot 1(2), 2.5.

Holt, S. J. (1989). Pollution and the seal epidemic. The Ecologist 19, 124.

Lavigne, D. M. \& Kovacs, K. M. (1988). Harps \& Hoods: Icebreeding Seals of the Northwest Atlantic. University of Waterloo Press, Waterloo, ON, Canada.

Law, R. J., Allchin, C. R. \& Harwood, J. (1989). Concentrations of organochlorine compounds in the blubber of seals from eastern and north-eastern England, 1988. Mar. Pollut. Bull. 20, 110-115.

Law, R. J., Allchin, C. R. \& Harwood, J. (1989). Seals, sense, and science; Law, Allchin and Harwood reply, Mar. Pollut. Bull. 20, $583-584$. 
Laws, R. M. \& Taylor, R. J. F. (1957). A mass dying of crabeater seals, Lobodon carcinophagus (Gray). Proc. Zool. Soc. Lond. 129, 315325.

Likhoshway, Ye. V., Grachev, M. A., Kumarev, V. P., Solodun, Yu. V., Goldberg, O. A., Belykh, O. I., Nagieva, F. G., Kikulina, V. G. \& Kolesnik, B. S. (1989). Baikal seal virus. Nature 339, 266.

Mahy, B. W. J., Barrett, T., Evans, S., Anderson, E. C. \& Bostock, C. J. (1988). Characterization of a seal morbillivirus. Nature 336, 115.

McCann, T. S. \& Doidge, D. W. (1987). Antarctic fur seal, Arctocephalus gazella. In Status, biology, and ecology of fur seals (J. P. Croxall and R. L. Gentry, eds), NOAA Technical Report NMFS 51 , 5-8.

McGourty, C. (1988a). Seal epidemic still spreading. Nature 334, 553.

McGourty, C. (1988b). Species jump may be responsible for seals virus infection. Nature 335, 3 .

Miller, J. A. (1989). Diseases for our future. Global ecology and emerging viruses. BioScience 39, 509-517.

Novak, M., Howlander, H. \& Krampetz, I. (1989). Long-term exposure effects of cold and heat on mouse peripheral leucocytes. $J$, therm. Biol. 14, 71-74.

Osterhaus, A. D. M. E. \& Vedder, E. J. (1989). No simplification in the etiology of recent seal deaths. Ambio 18, 297-298.

Osterhaus, A. D. M. E., Goren, J., Uytdehaag, F. G. C. M., Visser, I. K. G.. Bildt, M. W. G. v. d., Bergmang, A. \& Klingeborn, B. (1989). Distemper virus in Baikal seals. Nature 338, 209-210.

Perrin, W. F. (1988). Mass die-offs are a factor in survival of populations. An editorial. Newsletter of the Cetacean Specialist Group, International Union for Conservation of Nature and Natural Resources, 4, 10.

Ray, G. C. \& Fay, F. H. (1968). Influence of climate on the distribution of walruses. Odobenus rosmarus, Zoologica 53, 19-32

Revkin, A. C. (1989). Endless summer: Living with the greenhouse effect. Discover 9(10), 50-61.

Ruffner, J. A. \& Bair, F. E. (1987). Weather of U.S. cities. Gale Research, Detroit.

Sergeant, D. E., Ronald, K., Boulva, J. \& Berkes, F. (1978). The recent status of Monachus monachus. the Mediterranean monk seal. Biol. Cons. 14, 259-287.

Simmons, M. P. \& Johnson, P. A. (1989a). Seal deaths. New Scientist 122,69

Simmons, M. P. \& Johnson, P. A. (1989b). Seals, sense, and science. Mar. Pollut. Bull. 20, 580-583.

Strong, A. E. (1989). Greater global warming revealed by satellitederived sea-surface-temperature trends. Nature 338, 642-645 (1989). [The $x$-axis in Fig. 3 of this paper was inadvertently stretched relative to the data base; we obtained the original data directly from A. E. Strong, pers. comm. 27 Sept. 1989.1

Thomas, P. T. \& Faith, R. E. (1983). Adult and perinatal immunotoxicity induced by halogenated aromatic hydrocarbons. In Immuno toxicity and Immunophamacology (J. Dean et al., eds), pp. 305-313 Raven Press, New York.

Underdal, B., Skulberg, O. M., Dahl, E. \& Aune, T. (1989). Disastrous bloom of Chrysochromulina polylepis (Prymnesiophyceae) in Norwegian coastal waters 1988 -Mortality in marine biota. Ambio 18. $265-270$.

Vos, J. G., Van Loveren, H., Wester, P. W. \& Vethaak, A. D. (1988) The effects of environmental pollutants on the immune system. Experimental evidence and field observations. European Environment Review 2(3), 1-7.

\title{
Long Term Risks of Recurrent Seal Plagues
}

\author{
JOHN HARWOOD* and BRYAN GRENFELL ${ }^{*}$ \\ *Natural Environment Research Council, Sea Mammal Research Unit, High Cross, Madingley Road, Cambridge \\ CB3 OET; \\ ${ }^{\dagger}$ Department of Zoology, Austin Building, University of Cambridge, Pembroke Street, Cambridge CB2 3DX, UK
}

\begin{abstract}
There has been widespread speculation about the factors which contributed to the mass mortality of North Sea harbour seals during 1988 , and the threat that these factors pose to this and other marine mammal populations. We identify the questions which need to be answered before these speculations can be transformed into testable hypotheses and outline an epidemiological context for the preliminary evaluation of such hypotheses.
\end{abstract}

The epizootic which killed more than 17000 harbour seals (Phoca vitulina) around the coasts of Europe in 1988 is the largest and best documented case of mass mortality in marine mammals (Harwood \& Hall, in press). It is of particular scientific interest for a number of reasons: the size of the affected local populations had been monitored before the epizootic and will be monitored now that it is over; a high proportion of the animals which died were recovered and subject to pathological, bacteriological, and virological examination; and the speculation which surrounded the initial investigations received extensive coverage in the specialist and general press. Many of these speculations would not normally have been exposed to public view but, because they were widely publicized, they have been elevated to the status of working hypotheses (Harwood, 1990).

It is now widely accepted that the primary cause of the deaths was infection with a previously undescribed paramyxovirus from the morbilli family, which has been christened phocine distemper virus-PDV (Mahy et al., 1988; Cosby et al., 1988). However, a number of important questions about this particular epizootic remain unanswered. Persistent questions are: where did the virus come from? why did the epizootic occur when it did? why did it cause so many deaths? what was the contribution of other environmental factors? and what are the risks of future epizootics of this kind among marine mammal populations? In this paper we review 